\title{
An Experimental Study on Vertically Loaded Driven and Cast- In-Situ Piles
}

\author{
Ms.Vijaylaxmi.Dharmatti ${ }^{1}$, Dr.P.G.Rakaraddi ${ }^{2}$ \\ ${ }^{I}$ (PG Student, Department of Civil Engineering,Basaveshwar Engineering College, India) \\ ${ }_{2}^{2}$ (Professor, Department of Civil Engineering,Basaveshwar Engineering College, India)
}

\begin{abstract}
With the rapid growth of metropolitan areas and fast industrialization resulting from the fast-paced economic globalization, there has been a need to build heavier and taller structures on marginal sites, where surface soils are weak and shallow foundations are usually not the best design solution. In the present studybehaviors of the axially loaded driven and cast-in-situ piles were investigated. A several number of tests on different model piles like aluminium, wood and steel embedded in different density of sand i.e., $15.9 \mathrm{kN} / \mathrm{m}^{3}$ and $17.3 \mathrm{kN} / \mathrm{m}^{3}$ attained by sand raining technique were conducted. The model piles with outer diameter $15 \mathrm{~mm}$ and length $300 \mathrm{~mm}$ were used for single and group of piles which were subjected to axial compressive load. Smooth and rough piles were used and piles were made rough using standard epoxy and sand particles. The comparisons of ultimate load bearing capacity for different materials at different densities and at various modes of installation are described in the results. The experimental results showed that the axial compressive load varies for different material and ultimate load is more in driven piles as compared to the cast-in-situ piles. The pile capacity increases as the density of the sand increases.
\end{abstract}

Keywords:cast-in-situ piles, driven piles,sand,ultimate load.

\section{Introduction}

Piles are the structural members made of various materials like steel,wood, concrete etc, which are used to transmit load from superstructure to deeper soil strata. Pure friction piles tend to be quite long, since the loadcarrying capacity is a function of the shaft area in contact with the soil. In cohesionless soils, such as sands of medium to low density, driven piles are widely used to increase the density and thus the shear strength. Short, driven piles are frequently used in, where ground conditions indicate loose deposits of sands. Over the last few decades, the behaviour of pile or pile group has received a greatest attention of numerous investigators.

The behaviour of single piles under axial loading was examined in detail by many investigators and piles are often used in groups, they are most effective when combined in groups and the behavior of pile groups under the applied loads is generally different from that of a single individual pile due to the interaction of neighboring piles. The allowable load of single pile will not be the same when that pile is combined in group and their findings were outlined in several publications (Meyerhof 1976[1]; Vesic 1977[2]). Many investigator conducted experiments on single piles using axial compressive load in clay (Kraft et. al, 1981[3]; Briaud and Garland, 1985[4]; Horvath, 1995[5]; Al-Mhaidib, 2007[6]) and in sand (Al-Mhaidib 1999[7],2004[8]). In this present study test is conducted on driven and cast-in-situ piles using different materials in sand and both the results are compared.

It is, therefore, the research work is done to investigate the axial capacity of pile groups. In this it is presented the results of a series of single and model pile group tests performed in the geotechnical laboratory at Basaveshwar engineering college, Bagalkot, Karnataka, India. The study of pile and a group of piles of different materials such as wood, steel and aluminium are used of both smooth and rough surface. The piles used are of $15 \mathrm{~mm}$ diameter and $300 \mathrm{~mm}$ length and the soil medium used is of different density of sand. The sand bed prepared by using rainfall technique method. Pile surface were made rough using standard epoxy and sand particles. Two methods of installations are usedi.e., driven and cast-in-situ piles. The model piles are installed vertically and are subjected to axial compressive loads.

\section{Materials And Methodology}

The experimental work shows the physical and engineering properties of materials used in the present work and testing procedure.

\subsection{Test set up}

The test set up, a line diagram shown in the fig 1, consists of soil tank, piles and pile cap, screw jack, loading frame and dial gauges were used to conduct tests. The vertical load was applied using the screw jack. Proving ring and dial gauges were used for measuring loads and pile displacement respectively. 


\subsection{Sand tank}

The sand tank was made up of wood of size $750 \mathrm{~mm} \times 750 \mathrm{~mm} \times 750 \mathrm{~mm}$. The tank was strengthened in the horizontal direction using wooden strips to avoid the bulging of the tank during preparation of sand bed and also during loading process.

\subsection{Model piles}

The model piles used in this experimental study were smooth piles and rough pilesi.e, the surface of piles are made rough using standard epoxy adhesive and sand particles. Piles used in this study are of different materials viz., wood, steel and aluminium having diameter of $15 \mathrm{~mm}$ and length $300 \mathrm{~mm}$. Length to diameter ratio $(1 / \mathrm{d})=$ 20. For single and group of piles, pile cap was used of size $40 \mathrm{~mm} \times 40 \mathrm{~mm} \times 10 \mathrm{~mm}$ and for group of piles $90 \mathrm{~mm} \times 90 \mathrm{~mm} \times 10 \mathrm{~mm}$ sized pile cap was used. Both pile caps were made of steel plate. Pile spacing for group of pile $=3 \mathrm{~d}$, number of piles for group $=4$.

\subsection{Screw jack}

A hand operated jack gauge has been used in the present work, screw jack having a capacity of $5 \mathrm{~T}$.

\subsection{Sand properties}

The sand used for this study is from Krishna river sand, Krishna mandal, Andra Pradesh. A grain size distribution is shown in fig 2 . The basic and index properties of the sand are determined from laboratory experiments according to IS Code of practices and the values are summarized in Table 1.
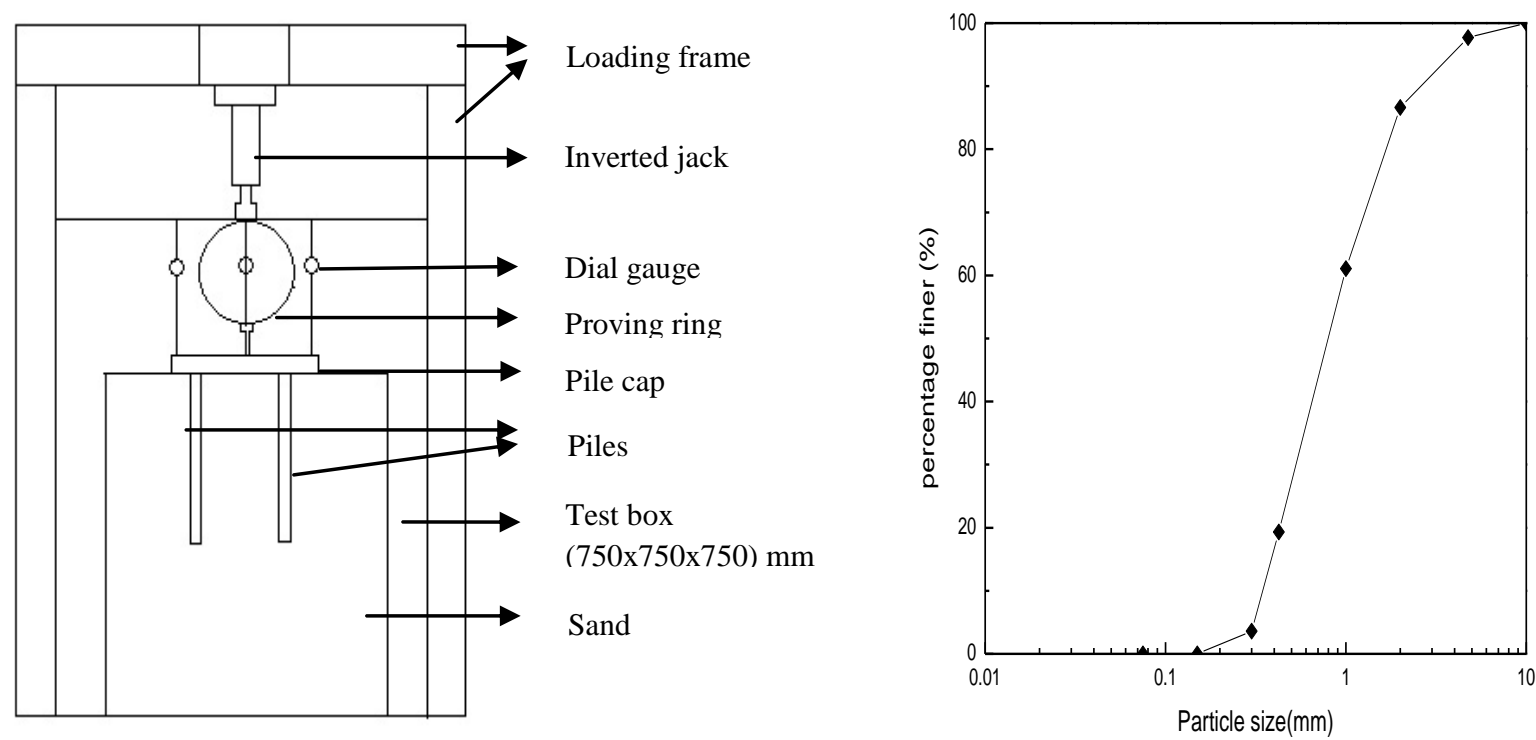

Fig 1.Schematic diagram of test set upFig 2. Grain size distribution of tested sand

Table1. Properties of sand used in the study

\begin{tabular}{|l|l|}
\hline \multicolumn{2}{|l|}{ Parameters } \\
\hline Effective Size, $\quad \mathrm{D}_{10}(\mathrm{~mm})$ & 0.43 \\
\hline \multicolumn{1}{|c|}{$\mathrm{D}_{30}(\mathrm{~mm})$} & 0.72 \\
\hline $\mathrm{D}_{60}(\mathrm{~mm})$ & 1.05 \\
\hline Uniformity coefficient $\left(\mathrm{C}_{\mathrm{u}}\right)$ & 2.44 \\
\hline Coefficient of curvature $\left(\mathrm{C}_{\mathrm{c}}\right)$ & 1.14 \\
\hline Specific Gravity $(\mathrm{G})$ & 2.62 \\
\hline Maximum dry unit weight $\left(\mathrm{kN} / \mathrm{m}^{3}\right)$ & 17.3 \\
\hline Minimum dry unit weight $\left(\mathrm{kN} / \mathrm{m}^{3}\right)$ & 15.9 \\
\hline Angle of internal friction $(\mathrm{degrees})$ & $39^{0}$ \\
\hline$\gamma=17.3\left(\mathrm{kN} / \mathrm{m}^{3}\right)$ & $30^{0}$ \\
\hline$\gamma=15.9\left(\mathrm{kN} / \mathrm{m}^{3}\right)$ & \\
\hline
\end{tabular}




\section{Experimental Work}

The present investigation was carried out in the geotechnical engineering laboratory of the civil engineering department, Basavaeshwar Engg., college, Bagalkot, India. All the model test were conducted using the setup shown infig 1, which consists of sand tank, model piles, loading frame ,dial gauges and proving ring. The vertical load was applied on the model pile using screw jack, which provides vertical displacement. A proving ring and dial gauge were used for measuring load and pile displacement respectively. The sand tank was made up of wooden box of inside length, width and height of the wooden box are $750 \mathrm{~mm}, 750 \mathrm{~mm}$ and $750 \mathrm{~mm}$ respectively. The tank was strengthened in horizontal directions using wooden strips to avoid lateral deformation/bulging of tank walls during filling of the sand bed and during loading conditions.

\subsection{Sand bed preparation}

For conducting model tests the sand bed was prepared in test tank using raining technique(Al-Mhaidib 2004[8]). The density achieved was confirmed by collecting samples in small container of known volume placed at different depths in the test tank at the time of filling and density of sand was determined. The values of density for samples collected from different depths in the sand bed were found to be almost same.

\subsection{Test process}

The model pile was placed on the center line alignment for the equal distribution of load on the pile cap. The driven pile was inserted directly and cast in situ pile was inserted using pipe. The vertical load was applied to the model pile using screw jack. The load and settlement of the model pile was measured using proving ring and two dial gauges located diagonally on each side of the pile cap capable of measuring movements to $0.01 \mathrm{~mm}$ respectively. The dial gauges were mounted on rigid steel section by means of magnetic bars. The displacements reported were average of the two dial gauge readings, which were nearly identical. Each test was conducted by recording, loading and settlement reading until the settlement was more than $10 \%$ of pile diameter. Before going for the next test the sand in the test tank was completely removed and then refilled with sand for the required density using the raining technique as described earlier.

In the present study method of pile installation was done by two type, one is driven and another one is cast-insitu. In the first case i.e., driven method, piles are driven or pushed in the sand. In the second case i.e., cast-insitu method, a hollow pipe is inserted of same length of pile but having diameter $1 \mathrm{~mm}$ greater than that of pile, both the ends of the pipe are closed temporarily so as to avoid entry of the sand inside pipe and then the sand was poured. Later on pile is inserted inside the pipe and without disturbing the pipe was removed, loading process is done.

\section{Results And Discussion}

There are several interpretation methods to evaluate the ultimate loads given by Vesic 1977[2];Mansur and Kaufman 1956[9]; Davison 1972[10]; Weltman 1980[11]; Hirany and Kulhaway 1989[12]. For the present study the ultimate load was determined by the tangent intersection method (Mansur and Kaufman 1956[9]) at the point of intersection of initial and final tangent to the load displacement curve. The discussions of the results obtained from the experiments carried out to examine

i) Settlement of pile for applied load.

ii) Behavior of pile material.

The results obtained for driven and cast-in-situ piles of different materials for the proposed density are shown in below tables and figures. The ultimate loads of each pile material for different densities were plotted, a driven smooth pile of density $15.9 \mathrm{kN} / \mathrm{m}^{3}$ is shown below in fig 3 is typical example of ultimate load through tangent method.

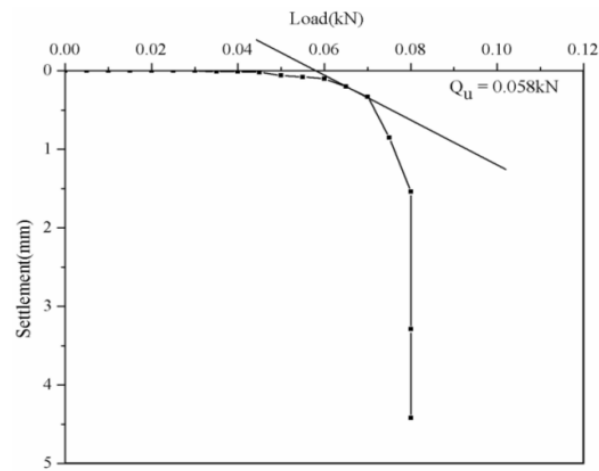

Fig 3. Showing a typical graph of wood pile of $15.9 \mathrm{kN} / \mathrm{m}^{3}$ 


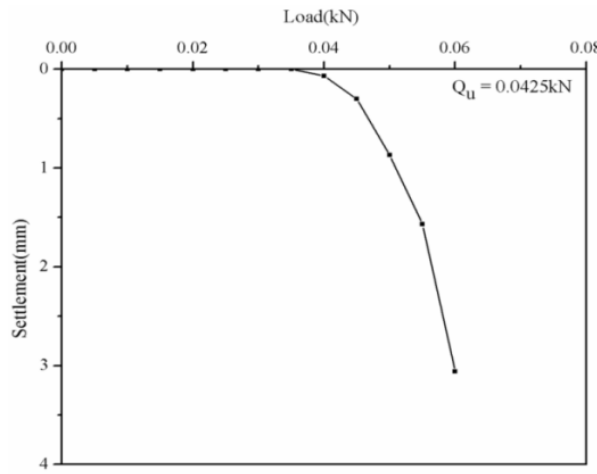

(a)

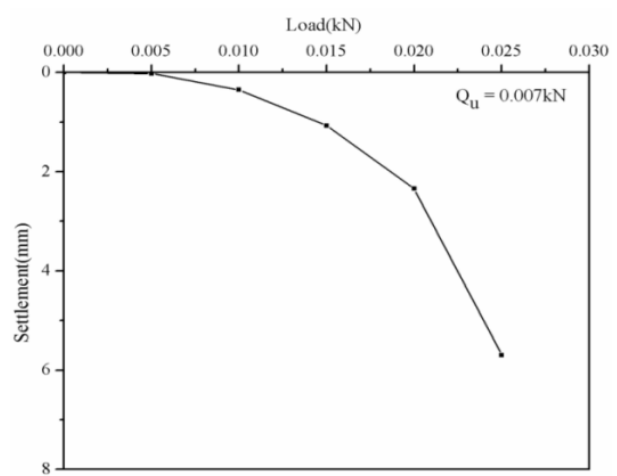

(b)

Fig 4.Shows load-settlement curve of smooth single pile: (a) driven steel pile of density $15.9 \mathrm{kN} / \mathrm{m}^{3}$ and (b) castin-situ steel pile of density $15.9 \mathrm{kN} / \mathrm{m}^{3}$.

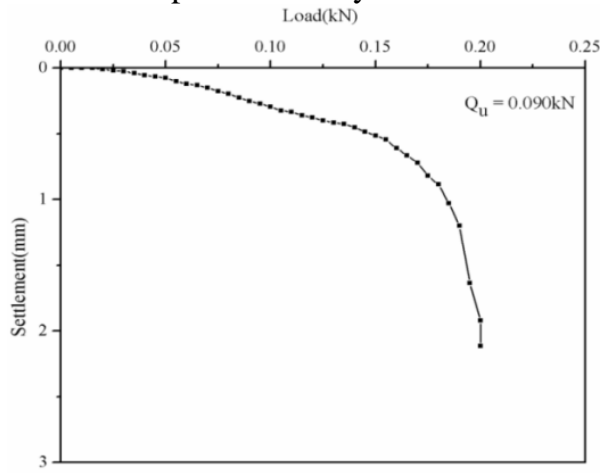

(a)

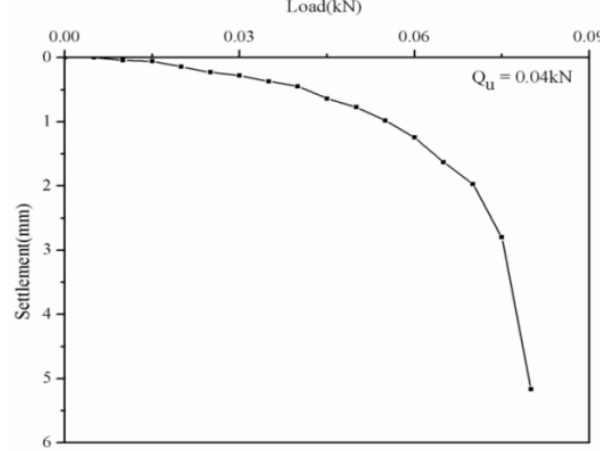

(b)

Fig 5.Showsload-settlement curve of rough single pile: (a) driven aluminium pile of density $17.3 \mathrm{kN} / \mathrm{m}^{3}$ and (b) cast-in-situ aluminium pile of density $17.3 \mathrm{kN} / \mathrm{m}^{3}$.

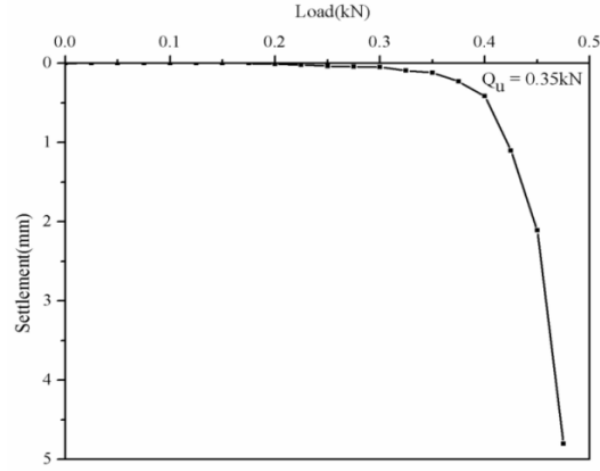

(a)

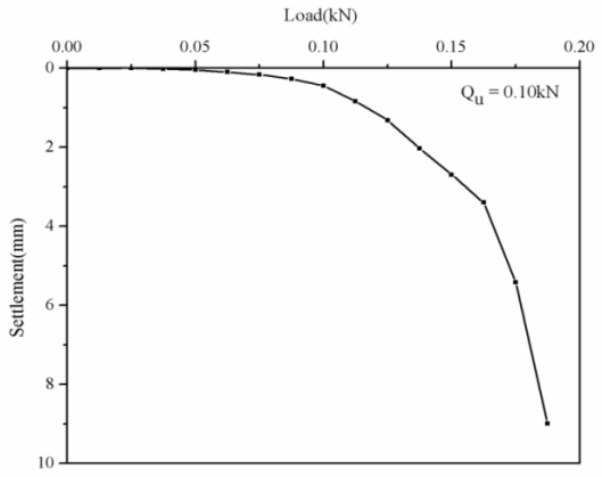

(b)

Fig 6.Shows load-settlement curve of smooth group piles: (a) driven wooden piles of density $15.9 \mathrm{kN} / \mathrm{m}^{3}$ and (b) cast-in-situ wooden piles of density $15.9 \mathrm{kN} / \mathrm{m}^{3}$.

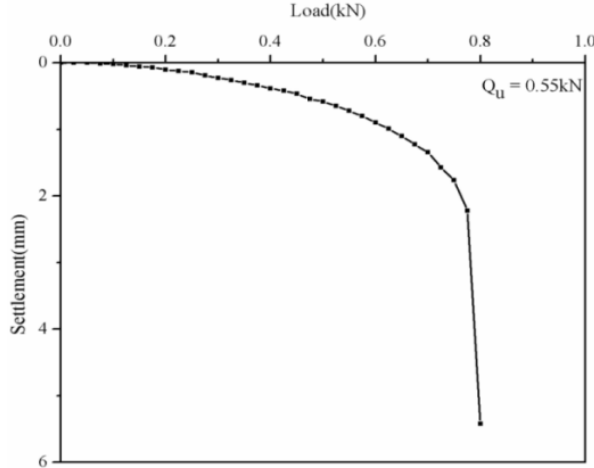

(a)

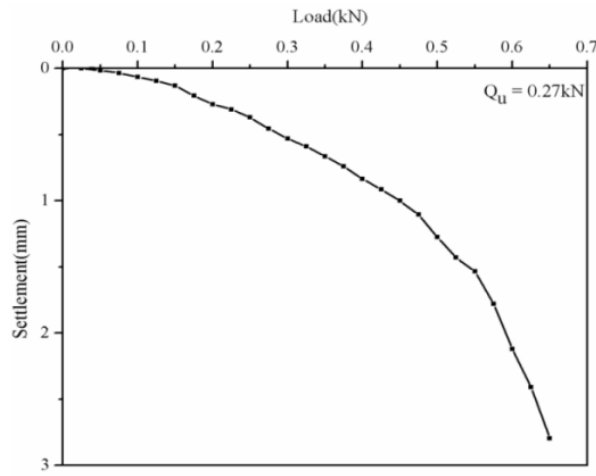

(b)

Fig 7.Shows load-settlement curve of rough group piles: (a) driven aluminium piles of density $17.3 \mathrm{kN} / \mathrm{m}^{3}$ and (b) cast-in-situ aluminium pile of density $17.3 \mathrm{kN} / \mathrm{m}^{3}$. 
Table2. Shows ultimate load of experimentally tested single piles.

\begin{tabular}{|l|l|l|l|l|l|l|l|}
\hline Method of $\begin{array}{l}\text { Density } \\
\text { installation } \\
\text { of sand } \\
\left(\mathrm{kN} / \mathrm{m}^{3}\right)\end{array}$ & \multicolumn{6}{|c|}{ Ultimate load $(\mathrm{kN})$} \\
\cline { 3 - 8 } & & Smooth Pile material & \multicolumn{3}{|c|}{ Rough pile material } \\
\cline { 3 - 8 } & & Wood & Aluminium & Steel & Wood & Aluminium & Steel \\
\hline Driven & 15.9 & 0.058 & 0.026 & 0.0425 & 0.065 & 0.070 & 0.050 \\
\cline { 3 - 8 } & 17.3 & 0.072 & 0.031 & 0.045 & 0.078 & 0.090 & 0.060 \\
\hline Cast-in-situ & 15.9 & 0.012 & 0.004 & 0.007 & 0.028 & 0.030 & 0.018 \\
\cline { 2 - 8 } & 17.3 & 0.016 & 0.005 & 0.011 & 0.030 & 0.040 & 0.027 \\
\hline
\end{tabular}

Table 3.Shows ultimate load of experimentally tested group of piles.

\begin{tabular}{|c|c|c|c|c|c|c|c|}
\hline \multirow{3}{*}{$\begin{array}{l}\text { Method of } \\
\text { installation }\end{array}$} & \multirow{3}{*}{$\begin{array}{l}\text { Density } \\
\text { of sand } \\
\left(\mathrm{kN} / \mathrm{m}^{3}\right)\end{array}$} & \multicolumn{6}{|c|}{ Ultimate load $(\mathrm{kN})$} \\
\hline & & \multicolumn{3}{|c|}{ Smooth Pile material } & \multicolumn{3}{|c|}{ Rough pile material } \\
\hline & & Wood & Aluminium & Steel & Wood & Aluminium & Steel \\
\hline \multirow[t]{2}{*}{ Driven } & 15.9 & 0.35 & 0.145 & 0.2 & 0.32 & 0.38 & 0.30 \\
\hline & 17.3 & 0.4 & 0.19 & 0.26 & 0.41 & 0.55 & 0.33 \\
\hline \multirow[t]{2}{*}{ Cast-in-situ } & 15.9 & 0.1 & 0.063 & 0.078 & 0.20 & 0.225 & 0.16 \\
\hline & 17.3 & 0.125 & 0.069 & 0.099 & 0.23 & 0.27 & 0.19 \\
\hline
\end{tabular}

\subsection{Load-settlement curves of smooth driven pile and smooth cast-in-situ pile}

The ultimate load $\left(\mathrm{Q}_{\mathrm{u}}\right)$ obtained from tangent intersection method for the density $15.9 \mathrm{kN} / \mathrm{m}^{3}$ and $17.3 \mathrm{kN} / \mathrm{m}^{3}$ of pile materials wood, steel and aluminium. From fig 4, fig 6, table 2 and table 3 it is clear that load carrying capacity of the pile depends on the pile material. The value of $\mathrm{Q}_{\mathrm{u}}$ increases with the increase in the density of the soil medium. It is clear that aluminium pile settles earlier than steel and wooden pile in density $15.9 \mathrm{kN} / \mathrm{m}^{3}$ and the same observation is made in $17.9 \mathrm{kN} / \mathrm{m}^{3}$ density in case of smooth driven pile(both single and group). When the loading rate increases the slope of the load-settlement curve also increases. In the cat-in-situ method as observed the slope of the all pile material has continuous steep slope. Initially the rate of increase of load is minimum upto certain load, later the slope increases as the loading rate increases. Smooth driven piles carry more load than smooth cast-in-situ piles.

\subsection{Load-settlement curves of rough driven pile and rough cast-in-situ pile}

From fig 5, fig 7, table 2 and table 3 which it is clear that load carrying capacity of the pile depends on the pile material and surface of pile material. The ultimate load $\left(\mathrm{Q}_{\mathrm{u}}\right)$ obtained for the density $15.9 \mathrm{kN} / \mathrm{m}^{3}$ and $17.3 \mathrm{kN} / \mathrm{m}^{3}$ of pile materials wood, steel and aluminium. The value of $\mathrm{Q}_{\mathrm{u}}$ increases with the increase in the density of the soil medium (Al-Mhaidib, 1999[7]). Due to the rough surface the friction is more and the piles have high load carrying capacity. In the case of the rough piles, driven piles has high ultimate load than the castin-situ piles.Settlement of the steel pile is earlier than the wooden and aluminium piles(both in case of single and group of piles).It is observed that in cast-in-situ pile the slope of the all pile material in both densities has continuous steep slope.

In the rough group of pile the ultimate load is high as compared to the smooth group of pile. This is because load carrying capacity depends on the pile material and pile surface.

The comparison made for group and single piles in the following by observing the results obtained for single pile and group of piles.

- It is clear that group of piles have more load carrying capacity than the single piles. Experimentally tested results showed that group of piles are almost 5-6 times greater load carrying capacity than the single piles. The driven smooth single aluminium pile carries a load of $0.045 \mathrm{kN}$ and driven smooth group of aluminium pile carries a load of $0.27 \mathrm{kN}$ for the density $17.3 \mathrm{kN} / \mathrm{m}^{3}$.

- The settlement of the single pile is earlier than group of piles. The cast-in-situ rough steel single and group of piles settles $0.1 \mathrm{~mm}$ at load $0.01 \mathrm{kN}$ and $0.1 \mathrm{~mm}$ at load $0.1 \mathrm{kN}$ for density $15.9 \mathrm{kN} / \mathrm{m}^{3}$ respectively.

\section{Conclusions}

Laboratorymodel test results for pile materials aluminium, steel and wood in sand for the density $15.9 \mathrm{kN} / \mathrm{m}^{3}$ and $17.3 \mathrm{kN} / \mathrm{m}^{3}$ have been conducted. Based on the results, following conclusions were drawn.

- The increase in the density of soil leads to the increase in load carrying capacity of single pile and group of piles both in driven and cast-in-situ piles.

- The rate of settlement is lesser at the initial loads and increases with the increase in the loading. 
- As the angle of wall friction increases, the ultimate bearing capacity of piles also increases.

- The ultimate load carrying capacity of the pile is high in case of driven piles as compared to cast-in-situ piles. For single rough surface aluminium driven pile, the ultimate load carrying capacity is $0.070 \mathrm{kN}$ and cast-in-situ is $0.030 \mathrm{kNat} 15.9 \mathrm{kN} / \mathrm{m}^{3}$ density. For aluminium group of piles having rough surface for driven and cast in situ the ultimate load carrying capacity is $0.38 \mathrm{kN}$ and $0.22 \mathrm{kN}$ at $15.9 \mathrm{kN} / \mathrm{m}^{3}$ density.

- The load carrying capacity of four piles placed in a group has 5 to 6 times greater load carrying capacity of single pile. The aluminium driven smooth single pile carries a load of $0.045 \mathrm{kN}$ and driven smooth group of pile carries a load of $0.27 \mathrm{kN}$ at density $15.9 \mathrm{kN} / \mathrm{m}^{3}$.

- For same testing condition, ultimate load of aluminium pile is found to be greater in rough driven and cast-in-situ piles.

- The wooden piles have more load carrying capacity in both smooth driven and smooth cast-in-situ piles.

Present work is carried out for static loading and this can be extended to the cyclic loading. The work has to be extended to different densities for different soils like black cotton soil etc.

\section{References}

[1]. Meyerhof.G.G.Bearing capacity and settlement of pile foundations,J.GeotechEng.Div., ASCE 102(3), 1976, pp. 197-228.

[2]. Vesic, A.S. Design of Pile Foundation, National Cooperative highway Practice No.42, Transportation Research board, Washington, D.C, 1977.

[3]. Kraft, L.M., Cox, W. R., and Verner, E. A. Pile Load Tests: Cyclic Loads and Varying Load Rates. Journal of Geotechnical Engineering, ASCE, 107, 1-19, 1981.

[4]. Briaud, J.L. and Garland, E. Loading Rate Method for Pile Response in Clay. Journal of Geotechnical Engineering, ASCE, 111,319335, 1985.

[5]. Horvath, R. G. Influence of Loading Rate on the Capacity of a Model Pile in Clay. Canadian Geotechnical Journal, 32,364-368, 1995.

[6]. Al-Mhaidib, A. I.Efficiency of Pile Groups in Clay under Different Loading RatesProceedings of the Sixteenth International Offshore and Polar Engineering Conference, Lisbon, Portugal, July 1-6, 2007

[7]. Al-Mhaidib, A. I.Bearing Capacity of a Model Pile in Sand under different Loading RatesProceedings of the Ninth International Offshore and Polar Engineering Conference (ISOPE-99),Brest, France, V. 1, 724-730, 1999.

[8]. Al-Mhaidib, A. I. Effect of Loading Rate on Pile groups in Sand International Conference on Geotechnical Engineering, SharjahUAE, October 3-6,2004.

[9]. Mansur, C.I. and Kaufman, J.M. Pile Tests, Low-Sill Structure, Old River, Louisiana. Journal of Soil Mechanics and Foundation Division, ASCE, 82(SM5), 1-33, 1956.

[10]. Davisson, M. T. High Capacity Piles. Proceedings, Lecture Series on Innovations in Foundation Construction, ASCE Illinois Section, Chicago 1972.

[11]. Weltman, A. J. Pile Load Testing Procedure. Report PG7, construction Industry Research and Information Association (CIRIA), London 1980.

[12]. Hirany, A and Kulhwy, F.H.Interpretation of Load tests on Drilled Shafts, Part 1: Axial Compression. Proceedings of the 1989 Foundation Engineering Congress, Foundation Engineering: Current Principles and Practices edited by F.H.Kulhawy, ASCE, Evanston, Illinois, V.2, 1132-1149, 1989. 